\title{
Survei Keterampilan Teknik Dasar Bolavoli Ekstrakurikuler Bolavoli Sekolah Menengah Atas
}

\author{
Arif Hadi Masroni*, Eko Hariyanto \\ Universitas Negeri Malang, Jl. Semarang No. 5 Malang, Jawa Timur, Indonesia \\ *Penulis korespondensi, Surel: arifroni96@gmail.com
}

Paper received: 3-5-2021; revised: 24-5-2021; accepted: 28-5-2021

\begin{abstract}
Abstrak
Penelitian ini bertujuan untuk mengetahui keterampilan teknik dasar service, passing, smash, block bolavoli peserta ekstrakurikuler bolavoli SMAN 1 Batu dan SMKN 1 Batu. Metode penelitian yang digunakan dalam penelitian ini adalah metode survei. Sampel dalam penelitian ini diambil menggunakan teknik probability proportional random sampling berjumlah 40 orang peserta ekstrakurikuler bolavoli SMK Negeri 1 Kota Batu dan SMA Negeri 1 Kota Batu. Instrumen pada penelitian ini menggunakan tes keterampilan bolavoli dari AAHPRED untuk tes service dan passing, untuk tes smash dan block dalam penelitian ini menggunakan BATTERY TEST bolavoli. Hasil tes siswa dianalisis menggunakan kriteria Penilaian Acuan Norma (PAN). Secara keseluruhan keterampilan teknik dasar bolavoli peserta ekstrakurikuler kedua sekolah tergolong cukup. Perlu adanya perbaikan jadwal dan program latihan, sehingga penguasaan keterampilan teknik dasar bolavoli bisa merata dan lebih baik dalam bermain bolavoli.
\end{abstract}

Kata kunci: survei; keterampilan teknik dasar bolavoli; ekstrakurikuler

\section{Pendahuluan}

Olahraga bolavoli merupakan permainan yang sangat populer di Indonesia. Hampir di setiap daerah memiliki lapangan voli, selain mudah untuk dilakukan, olahraga bolavoli juga tidak memerlukan lapangan yang luas seperti pada olahraga sepakbola, sering kali di desa-desa diadakan kompetisi bolavoli yang biasa disebut dengan tarkam atau antar kampung, dan peminatnya pun juga sangat banyak.

Bolavoli adalah olahraga yang dimainkan oleh dua tim yang bertanding menggunakan tangan dan dipisahkan oleh sebuah net, kemudian setiap tim berusaha menjatuhkan bola di area lapangan lawan dengan memukul bola melewati atas net, setiap tim memiliki enam pemain inti dan beberapa pemain cadangan. Pada permainan bolavoli diperlukan kerjasama yang baik dari para pemain sehingga dapat memenangkan pertandingan. Selain kerjasama di dalam permainan bolavoli juga ada beberapa teknik dasar yang harus dikuasai oleh pemain, seperti service, passing, smash, dan block. Teknik dasar itu harus dikuasai oleh pemain, jika salah satu teknik dasar tersebut tidak dapat dikuasai dengan baik oleh pemain, maka akan mengalami kesulitan dalam bermain bolavoli dan timnyapun juga akan sulit untuk meraih kemenangan.

Service adalah teknik yang paling mendasar dalam bolavoli. Service merupakan pukulan awal dari pemain untuk memulai pertandingan, menurut Winarno, dkk. (2015) "Service merupakan pukulan sajian awal untuk memulai suatu pertandingan atau permainan bolavoli, sekaligus serangan pertama bagi regu yang melakukan service". Menurut Yuniawan, dkk., 2012, service merupakan suatu upaya memasukkan bola ke daerah lawan oleh pemain belakang yang berada pada daerah service untuk memukul bola dengan satu tangan atau lengan. Selain untuk memulai permainan, service juga dapat digunakan sebagai serangan jika dilakukan dengan baik 
dan keras sehingga menyulitkan lawan. Jika service tidak dikuasai maka secara otomatis permainan bolavoli tidak akan bisa berjalan dan akan menghasilkan poin untuk lawan, umumnya ada dua jenis service yang bisa dilakukan oleh pemain yaitu service atas dan service bawah, tapi jika ingin melakukan service sebagai serangan maka harus menggunakan service atas karena bola yang dipukul akan lebih keras dan menyulitkan lawan.

Passing berarti mengumpan atau mengoper bola. Menurut Winarno, dkk. (2015) "Passing berarti mengumpan atau mengoper bola kepada kawan satu regu", teknik dasar yang paling sering digunakan dalam permainan bolavoli. Selain itu passing menjadi modal utama bagi pemain bolavoli, jika passing yang dimiliki seorang pemain bagus maka serangan yang akan dilakukan akan lebih mudah, akan tetapi jika passing yang dimiliki seorang pemain kurang bagus atau buruk maka serangan yang akan dilakukan juga akan sulit, passing ada dua macam yaitu passing bawah dan passing atas. Passing bawah dapat digunakan untuk menerima smash dan menerima bola liar yang tidak terkendali (Anggraini, dkk., 2016).

Smash merupakan pukulan keras yang digunakan untuk mengakhiri serangan. Menurut Winarno, dkk. (2015) "Teknik dasar yang paling dominan untuk meraih poin pada saat permainan bolavoli dilakukan adalah teknik dasar smash", jika teknik smash tidak dikuasai maka tim lawan akan dengan mudah dapat menerima dan mengatasi serangan yang akan dilakukan dan timnya akan sulit mendapatkan poin, biasanya pemain yang memiliki smash bagus akan diposisikan di depan dan sering diberikan umpan untuk untuk kemudian dilakukan pukulan smash.

Block merupakan teknik yang digunakan untuk menahan serangan lawan. Menurut Winarno, dkk. (2015) "Pada dasarnya block adalah suatu teknik dengan cara merintangi atau menghalangi bola ketika pemain lawan sedang melakukan serangan di depan net", block dilakukan dengan kedua tangan saat tim lawan melakukan smash, jika pemain memiliki block yang bagus maka bola hasil dari block yang dilakukan akan masuk ke area lapangan tim lawan dan akan menghasilkan poin, akan tetapi jika bola hasil dari block keluar maka akan menghasilkan poin bagi lawan.

Ekstrakurikuler merupakan suatu kegiatan atau aktivitas tambahan di luar jam mata pelajaran. Kompri (2015) menyatakan, "Ekstrakurikuler memiliki arti kegiatan tambahan di luar rencana pembelajaran atau pendidikan di luar kurikulum". Ekstrakurikuler di sekolah kebanyakan adalah kegiatan yang berupa aktivitas fisik seperti olahraga, dan pramuka, tetapi ada juga ekstrakurikuler yang kegiatannya berupa non fisik seperti ekstrakurikuler bahasa Inggris, Jepang, dan Mandarin. Dalam hal ini yang akan kita bahas adalah ekstrakurikuler yang kegiatannya berupa aktivitas fisik atau olahraga, yaitu ekstrakurikuler bolavoli.

Ekstrakurikuler bolavoli adalah suatu kegiatan di luar jam pelajaran yang bertujuan untuk mewadahi bakat minat dalam bermain bolavoli yang dimiliki siswa. Tidak hanya untuk siswa yang memiliki bakat dalam bermain bolavoli saja, ekstrakurikuler bolavoli juga bisa diikuti oleh siswa yang tidak bisa sama sekali bermain bolavoli dan ingin belajar bermain bolavoli, ekstrakurikuler bolavoli juga dapat menanamkan jiwa sportivitas, disiplin, dan bertanggung jawab kepada siswa. Secara keseluruhan ekstrakurikuler bolavoli bisa menjadi suatu wadah yang menampung bakat minat siswa untuk bermain bolavoli. Pembinaan siswa akan jauh lebih baik jika dilakukan menggunakan metode pembelajaran yang baik pula, karena latihan adalah suatu faktor utama dalam upaya mengembangkan skill atau keterampilan seorang pemain bolavoli. Menjadi seorang pemain bolavoli yang baik, siswa dituntut harus 
menguasai semua teknik dasar yang ada di dalam permainan bolavoli, karena teknik dasar adalah modal awal yang sangat penting bagi seorang pemain. Listina (2012) mengatakan, "Penguasaan teknik dasar yang baik akan memudahkan seorang pemain dalam menjalankan strategi dan akan timbul rasa percaya diri yang tinggi serta selalu optimis dalam setiap pertandingan", dengan latihan yang rutin minimal tiga kali dalam satu minggu dan program latihan yang bagus maka penguasaan teknik dasar tersebut akan lebih mudah tercapai. Latihan berfungsi sebagai balikan atau penguatan dan merupakan kondisi yang diperlukan untuk mengembangkan sebuah keterampilan (Siswanto, 2012).

Kota Batu terdapat satu Sekolah Menengah Atas (SMA) dan satu Sekolah Menengah Kejuruan (SMK) yang memiliki ekstrakurikuler bolavoli cukup bagus. Sekolah tersebut yaitu SMA Negeri 1 Kota Batu dan SMK Negeri 1 Kota Batu, tentunya kedua sekolah tersebut memiliki perbedaan karakter dari segi pembelajaran maupun karakteristik siswanya. Pembelajaran di SMK Negeri 1 Kota Batu seperti halnya sekolah kejuruan, lebih banyak kegiatan praktiknya dibandingkan dengan SMA Negeri 1 Kota Batu yang bisa dibilang sangat sedikit kegiatan praktiknya. Karakteristik siswanya terdapat perbedaan antara siswa SMA dengan siswa SMK, kebanyakan siswa yang bersekolah di SMA akan lebih tekun dan rajin, sedangkan siswa SMK biasanya lebih telaten dan mandiri. Namun baik siswa SMA ataupun SMK sama-sama masih dalam masa pubertas yang emosinya masih naik turun sehingga perlu adanya motivasi dari guru atau pelatih agar mereka bisa konsisten dalam melakukan latihan bolavoli.

Peneliti telah melakukan observasi dan wawancara kepada pelatih ekstrakurikuler bolavoli di kedua sekolah, hasilnya diketahui bahwa jumlah peserta ekstrakurikuler bolavoli di SMK Negeri 1 Kota Batu berjumlah 20 siswa dan latihan dilakukan sebanyak dua kali dalam seminggu. Sedangkan di SMA Negeri 1 Kota Batu jumlah peserta ekstrakurikuler bolavoli berjumlah 25 siswa dan latihan dilakukan sebanyak dua kali dalam satu minggu. Kedua sekolah tersebut sama-sama memiliki pelatih yang belum mendapatkan lisensi. Sarana dan prasarana kedua sekolah juga memiliki lapangan bolavoli yang cukup baik untuk menggelar latihan dan untuk fasilitas bolavoli SMA Negeri 1 Kota Batu memiliki 20 bola sedangkan SMK Negeri 1 KoTA Batu memiliki 15 bola. Dari data tersebut, timbul permasalahan yaitu intensitas latihan yang kurang, dimana kedua sekolah tersebut hanya melakukan latihan dua kali dalam satu minggu dan juga tenaga pelatih yang sama-sama belum memiliki lisensi kepelatihan.

Berdasarkan uraian di atas, peneliti beranggapan bahwa perlu adanya survei penelitian tentang keterampilan teknik dasar bolavoli pada siswa peserta ekstrakurikuler bolavoli di SMA Negeri 1 Kota Batu dan di SMK Negeri 1 Kota Batu. Dari survei penelitian nanti akan diperoleh hasil, tingkat penguasaan teknik dasar bolavoli pada peserta ekstrakurikuler dari kedua sekolah tersebut dilihat dari kedua sekolah tersebut memiliki proses atau karakter pembelajaran yang berbeda. Dengan uraian yang telah dikemukakan tersebut, peneliti akan melakukan penelitian yang berjudul "Survei Keterampilan Teknik Dasar Bolavoli Ekstrakurikuler Bolavoli Di SMA Negeri 1 Batu dan SMK Negeri 1 Batu".

\section{Metode}

\subsection{Rancangan Penelitian}

Ditinjau dari masalah yang diteliti, metode penelitian yang digunakan dalam penelitian ini adalah metode survei. Metode survei digunakan untuk mendapatkan data dari tempat 
tertentu yang alamiah (bukan buatan), tetapi peneliti melakukan perlakuan dalam pengumpulan data (perlakuan tidak seperti dalam eksperimen), misalnya kuesioner, tes, dan wawancara (Sugiyono, 2014). Dalam penelitian ini yang akan digunakan untuk mengumpulkan data adalah tes keterampilan.

\subsection{Data Penelitian}

Penelitian ini dilaksanakan di dua tempat yang berbeda yaitu SMK Negeri 1 Kota Batu dan SMA Negeri 1 Kota Batu dengan melakukan tes keterampilan teknik dasar bolavoli ekstrakurikuler bolavoli di kedua sekolah tersebut. Penelitian dimulai pada tanggal 21 Juli 2019 sampai Agustus 2019. Populasi peserta ekstrakurikuler bola voli SMK Negeri 1 Kota Batu berjumlah 20 orang dan di SMA Negeri 1 Kota Batu berjumlah 25 orang, sehingga total populasi berjumlah 45 orang. Sampel menurut Winarno (2017) bagian populasi Sampel dalam penelitian ini diambil menggunakan teknik probability proportional random sampling dengan mengambil 20 orang dari masing-masing sekolah, sehingga total sampel berjumlah 40 orang.

\subsection{Teknik Pengumpulan Data}

Teknik yang digunakan oleh peneliti dalam pengumpulan data adalah dengan menggunakan teknik pengukuran bentuk tes yaitu tes keterampilan teknik dasar bolavoli. Tes merupakan salah satu instrumen yang dapat digunakan sebagai dasar dalam memberikan penilaian (evaluasi) pada peserta didik terhadap materi yang diberikan baik materi teori maupun materi praktik dalam domain psikomotorik. Tes sebagai alat untuk memperoleh informasi tentang karakteristik peserta didik atau sifat suatu objek (Nurrochmah, 2016).

\subsection{Analisis Data}

Analisis data atau disebut juga penggolongan data adalah suatu langkah penting dalam penelitian. Di dalam penelitian ini peneliti menggunakan metode analisis dengan perhitungan statistik menggunakan analisis distribusi persentase (Arikunto, 2003). Rumus yang akan digunakan adalah sebagai berikut.

$P=x 100 \%$

$\mathrm{P}=$ Angka persentase

$\mathrm{F}=$ Frekuensi yang sedang dicari persentasenya

$\mathrm{N}=$ Jumlah responden

Pengkategorian tersebut menggunakan mean dan standar deviasi, menurut Anas Sudijono (2005) untuk menentukan kriteria skor dengan menggunakan penilaian acuan norma (PAN). Dalam skala yang sudah dimodifikasi berdasarkan Tabel 1 berikut.

Tabel 1 Kriteria Penilaian Acuan Norma (PAN), (Sumber:Anas Sudjiono, 2005)

\begin{tabular}{cc}
\hline Interval & Kategori \\
\hline$M+1,5 S>X$ & BaikSekali \\
$M+0,5 S<X \leq M+1,5 S$ & Baik \\
$M-0,5 S<X \leq M+0,5 S$ & Cukup \\
$M-1,5 S<X<M-0,5 S$ & Kurang \\
$X<M-1,5 S$ & Kurang Sekali \\
\hline
\end{tabular}




\section{Hasil dan Pembahasan}

\subsection{Hasil}

Berdasarkan hasil penelitian yang telah dilakukan diperoleh data penelitian tes keterampilan teknik dasar bolavoli terdapat 20 siswa peserta ekstrakurikuler bolavoli SMA Negeri 1 Batu dan 20 siswa SMK Negeri 1 Batu, sehingga total terdapat 40 testi yang kemudian dianalisis dengan statistik, deskriptif, dan kuantitatif. Dalam bab ini akan disajikan hasil penelitian tentang survei keterampilan teknik dasar bolavoli pada peserta ekstrakurikuler bolavoli SMA Negeri 1 Batu dan SMK Negeri 1 Batu. Analisis menggunakan tabel PAN, maka dari hasil analisis diperoleh hasil sebagai berikut

\subsubsection{SMA Negeri 1 Batu}

Keterampilan teknik dasar bolavoli di SMA Negeri 1 Batu dituliskan pada Tabel 2 berikut.

Tabel 2. Hasil Tes Keterampilan Teknik Dasar Bolavoli SMA Negeri 1 Batu

\begin{tabular}{clccccc}
\hline No & Variabel & Jumlah & $\begin{array}{c}\text { Skor } \\
\text { Maksimal }\end{array}$ & $\begin{array}{c}\text { Skor } \\
\text { Minimal }\end{array}$ & Rata-rata & SD \\
\hline 1 & Service Bawah & 20 & 33 & 16 & 28,35 & 4.50 \\
2 & Passing Bawah & 20 & 17 & 8 & 11,5 & 2.3 \\
3 & Passing Atas & 20 & 17 & 7 & 12,5 & 2.6 \\
4 & Smash & 20 & 33 & 15 & 24,1 & 4.5 \\
5 & Block & 20 & 29 & 12 & 17,1 & 4.2 \\
\hline
\end{tabular}

Berdasarkan sajian data pada Tabel 2 dapat diketahui hasil dari tes keterampilan teknik dasar bolavoli pada peserta ekstrakurikuler bolavoli SMA Negeri 1 Batu sejumlah 20 orang, memperoleh hasil untuk tes service atas yaitu nilai maksimal 33; nilai minimal 16; rata-rata 23,15 dan standar deviasi (SD) 4,34. Tes passing bawah memperoleh hasil yaitu nilai maksimal 17; nilai minimal 8; rata-rata 11,5 dan standar deviasi (SD) 2,3. Tes passing atas memperoleh hasil yaitu nilai maksimal 17; nilai minimal 7; rata-rata 12,5 dan standar deviasi (SD) 2,6. Tes smash memperoleh hasil yaitu nilai maksimal 33; nilai minimal 15; rata-rata 24,1 dan standar deviasi (SD) 4,5. Tes block memperoleh hasil yaitu nilai maksimal 29; nilai minimal 12; ratarata 17,1 dan standar deviasi (SD) 4,2.

\subsubsection{SMK Negeri 1 Batu}

Keterampilan teknik dasar bolavoli di SMK Negeri 1 Batu dituliskan pada Tabel 3 berikut.

Tabel 3 Hasil Tes Keterampilan Teknik Dasar Bolavoli SMK Negeri 1 Batu

\begin{tabular}{clccccc}
\hline No & Variabel & Jumlah & $\begin{array}{c}\text { Skor } \\
\text { Maksimal }\end{array}$ & $\begin{array}{c}\text { Skor } \\
\text { Minimal }\end{array}$ & Rata-rata & SD \\
\hline 1 & Service Bawah & 20 & 31 & 15 & 26,6 & 4,7 \\
2 & Passing Bawah & 20 & 16 & 7 & 11,2 & 2,2 \\
3 & Passing Atas & 20 & 17 & 7 & 12 & 2,7 \\
4 & Smash & 20 & 28 & 14 & 21,8 & 3,1 \\
\hline
\end{tabular}




\begin{tabular}{ccccccc}
\hline No & Variabel & Jumlah & $\begin{array}{c}\text { Skor } \\
\text { Maksimal }\end{array}$ & $\begin{array}{c}\text { Skor } \\
\text { Minimal }\end{array}$ & Rata-rata & SD \\
\hline 5 & Block & 20 & 28 & 11 & 16,5 & 4,4 \\
\hline
\end{tabular}

Berdasarkan hasil tes keterampilan teknik dasar bolavoli pada peserta ekstrakurikuler bolavoli SMK Negeri 1 Batu sejumlah 20 orang, memperoleh hasil untuk tes service atas yaitu nilai maksimal 31; nilai minimal 16; rata-rata 24,9; standar deviasi (SD) 3,8. Tes passing bawah memperoleh hasil yaitu nilai maksimal 16; nilai minimal 7; rata-rata 11,2; standar deviasi (SD) 2,2. Tes passing atas memperoleh hasil yaitu nilai maksimal 17; nilai minimal 7; rata-rata 12; standar deviasi (SD) 2,7. Tes smash memperoleh hasil yaitu nilai maksimal 28; nilai minimal 14; rata-rata 21,8; standar deviasi (SD) 3,1. Tes block memperoleh hasil yaitu nilai maksimal 28; nilai minimal 11; rata-rata 16,5; standar deviasi (SD) 4,4.

Menguasai keterampilan teknik dasar dalam bolavoli merupakan faktor penting agar dapat bermain bolavoli dengan terampil. Listina (2012) menyatakan, "Penguasaan teknik dasar yang baik akan memudahkan seorang pemain dalam menjalankan strategi dan akan timbul rasa percaya diri yang tinggi serta selalu optimis dalam setiap pertandingan". Permainan bolavoli merupakan permainan yang kompleks yang tidak mudah dilakukan oleh setiap orang (Ahmadi, 2007). Sebab, dalam permainan bolavoli dibutuhkan koordinasi gerak yang benar-benar bisa diandalkan untuk melakukan semua gerakan yang ada dalam permainan bolavoli.

\subsection{Pembahasan}

Siswa yang mendapatkan nilai kurang dan kurang sekali rata-rata melakukan kesalahan yaitu pukulan yang dilakukan kurang keras dan terarah sehingga tidak masuk ke dalam area sasaran. Menurut Winarno, dkk. (2015) menyatakan kesalahan-kesalahan yang dilakukan pemain dapat menyebabkan kegagalan dalam melakukan service. Selain itu, menurut penelitian Syaleh (2017) yang menyebabkan service atas kurang maksimal yaitu siswa belum sempurna dalam melakukan gerakan service atas utamanya pada sikap awalan, siswa belum bisa fokus pada gerakan-gerakan yang dilakukan, dan gerakan siswa yang masih kaku. Perbedaan perolehan nilai tes service atas pada SMA Negeri 1 Batu dan SMK Negeri 1 Batu dapat dilihat pada Gambar 1 berikut.

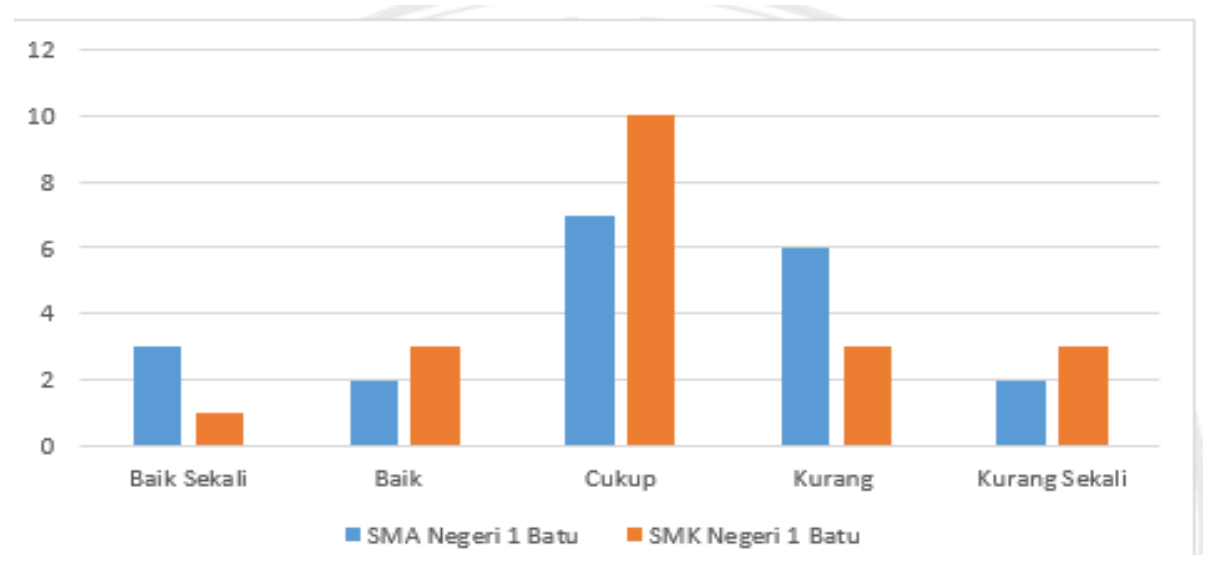

Gambar 1. Perbedaan Perolehan Nilai Tes Service Atas SMA Negeri 1 Batu dan SMK Negeri 1 Batu 
Siswa yang mendapatkan nilai kurang dan kurang sekali rata-rata perkenaan bola pada saat melakukan passing terlalu dekat dengan pergelangan tangan sehingga bola menjadi tidak terkontrol dengan baik. Menurut Winarno, dkk. (2015) menyatakan perkenaan lengan dengan bola berada pada lengan bagian atas pergelangan tangan dan di bawah siku. Sesuai dengan penelitian Anggraini, dkk. (2016) bahwa siswa mengalami kesulitan pada saat melakukan passing bawah ketika memposisikan tangan dan impact bola, ini terjadi karena siswa tidak menguasai teknik passing bawah, gerakan yang kurang sempurna dan mengalami kesulitan pada saat posisi tangan dan impact bola tidak tepat pada bagian pergelangan tangan. Perbedaan perolehan nilai tes passing bawah pada SMA Negeri 1 Batu dan SMK Negeri 1 Batu dapat dilihat pada Gambar 2 berikut.

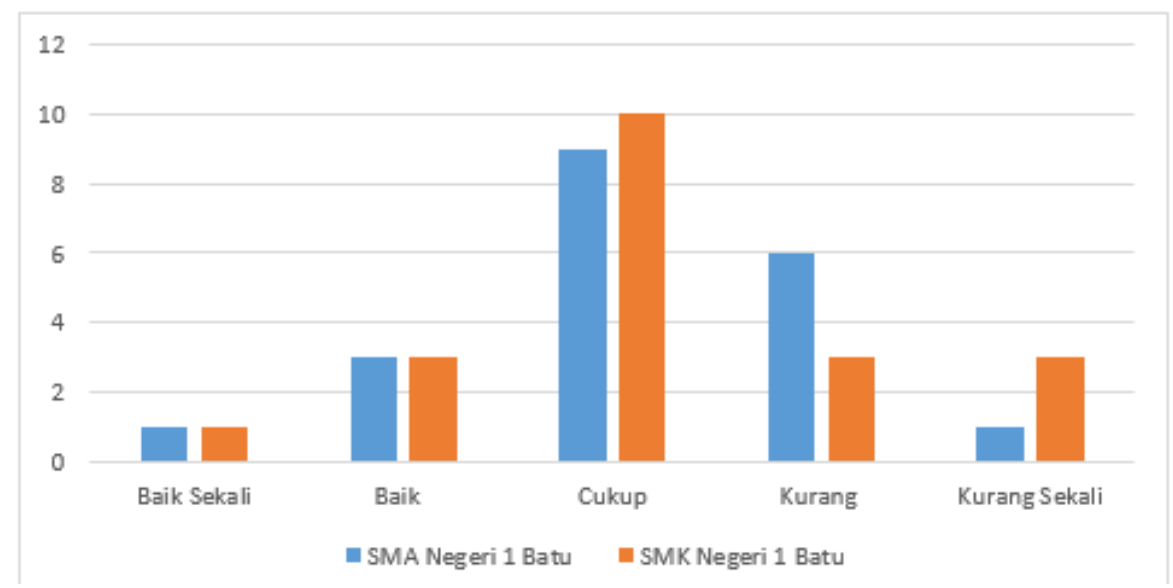

\section{Gambar 2. Perbedaan Perolehan Nilai Tes Passing Bawah SMA Negeri 1 Batu dan SMK Negeri 1 Batu}

Siswa yang mendapatkan nilai kurang dan kurang sekali rata-rata ayunan pergelangan tangan yang dilakukan saat bola bersentuhan dengan jari-jari tidak seirama sehingga kesulitan dalam mengarahkan bola, seperti yang dijelaskan Winarno, dkk. (2015) ketika jari bersentuhan dengan bola, jari-jari agak ditegangkan sedikit, dan bersamaan dengan itu diikuti dengan gerakan pergelangan tangan ke arah depan atas dengan gerakan yang eksplosif. Perbedaan perolehan nilai tes passing atas pada SMA Negeri 1 Batu dan SMK Negeri 1 Batu dapat dilihat pada Gambar 3 berikut.

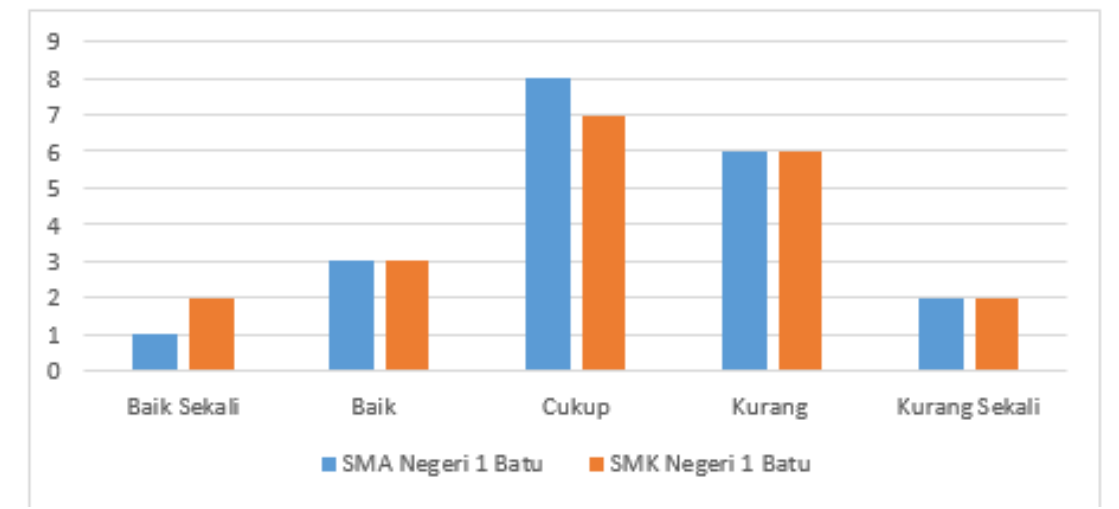

Gambar 3. Perbedaan Perolehan Nilai Tes Passing Atas SMA Negeri 1 Batu dan SMK Negeri 1 Batu 
Siswa yang mendapatkan nilai kurang dan kurang sekali rata-rata momentum pada saat melakukan pukulan kurang tepat sehingga pukulan yang dihasilkan tidak dapat mencapai sasaran. Kesalahan yang banyak dilakukan oleh siswa saat melakukan smash yaitu posisi badan yang tidak benar, perkenaan tangan dan bola, dan saat ayunan lengan saat melakukan service masih terdapat kesalahan (Fallo dan Hendri, 2016). Perbedaan perolehan nilai tes smash pada SMA Negeri 1 Batu dan SMK Negeri 1 Batu dapat dilihat pada Gambar 4 berikut.

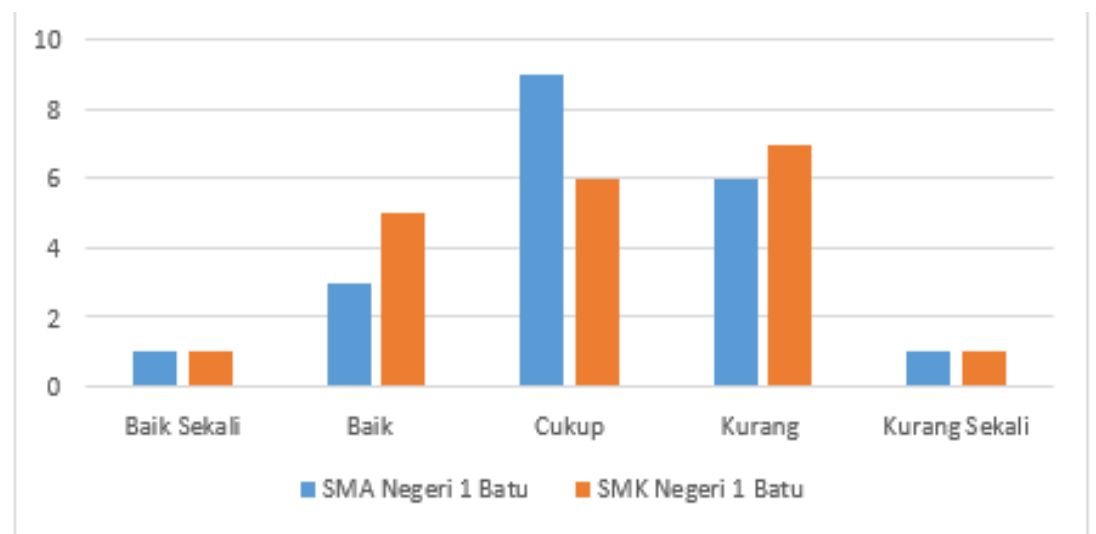

Gambar 4. Perbedaan Perolehan Nilai Tes Smash SMA Negeri 1 Batu dan SMK Negeri 1 Batu

Siswa yang mendapatkan nilai kurang rata-rata sikap awal yang dilakukan salah dan posisi telapak tangan kurang membuka, sehingga ketika bola yang dipukul lawan dan mengenai tangan pantulan yang dihasilkan tidak mengarah ke sasaran, seperti yang dikatakan Winarno, dkk. (2015) pada saat sikap awal berdiri tegak bertumpu pada kedua kaki menghadap ke net, kedua tangan diletakkan di depan dada dan telapak tangan posisi membuka. Menurut penelitian (Wahyuda, dkk., 2016) siswa mengalami kesalahan pada posisi tangan dan kesalahan dalam sikap akhir setelah melakukan gerakan block. Perbedaan perolehan nilai tes block pada SMA Negeri 1 Batu dan SMK Negeri 1 Batu dapat dilihat pada Gambar 5 berikut.

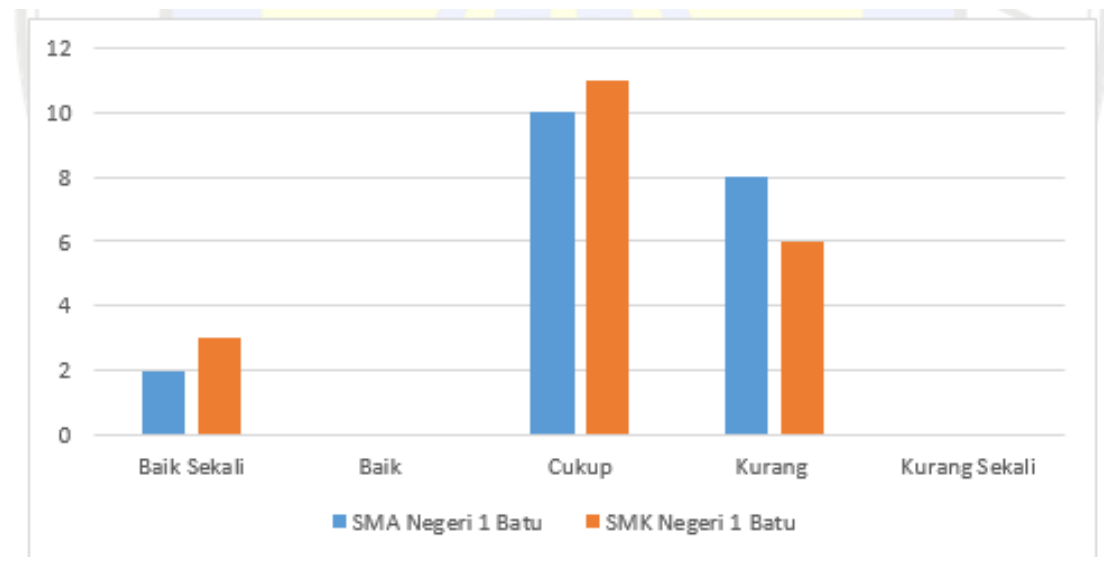

Gambar 5. Perbedaan Perolehan Nilai Tes Block SMA Negeri 1 Batu dan SMK Negeri 1 Batu

\section{Simpulan}

Berdasarkan dari berbagai proses yang telah dilakukan oleh peneliti, peneliti memperoleh data tentang kemampuan keterampilan teknik dasar bolavoli peserta ekstrakurikuler bolavoli SMA Negeri 1 Batu dan SMK Negeri 1 Batu. Hasil dan pembahasan dapat disimpulkan sebagai berikut: Kemampuan keterampilan teknik dasar bolavoli di SMA 
Negeri 1 Batu untuk tes service, berdasarkan nilai rata-rata tes service atas, yaitu 23,15, termasuk dalam kategori "cukup". Untuk tes passing bawah, berdasarkan nilai rata-rata tes passing bawah, yaitu 11,5, termasuk dalam kategori "cukup". Tes passing atas, berdasarkan nilai rata-rata tes passing atas, yaitu 12,5, termasuk dalam kategori "cukup". Tes smash, berdasarkan nilai rata-rata tes smash, yaitu 24,1, termasuk dalam kategori "cukup". Dan untuk tes block, berdasarkan nilai rata-rata tes block, yaitu 17,1, termasuk dalam kategori "cukup".

Kemampuan keterampilan teknik dasar bolavoli di SMK Negeri 1 Batu untuk tes service atas, berdasarkan nilai rata-rata tes service atas, yaitu 24,9, termasuk dalam kategori "cukup". Untuk tes passing bawah, berdasarkan nilai rata-rata tes passing bawah, yaitu 11,2, termasuk dalam kategori "cukup". Tes passing atas, berdasarkan nilai rata-rata tes passing atas, yaitu 12, termasuk dalam kategori "cukup". Tes smash, berdasarkan nilai rata-rata tes smash, yaitu 21,8, termasuk dalam kategori "cukup". Dan untuk tes block, berdasarkan nilai rata-rata tes block, yaitu 16,5 , termasuk dalam kategori "cukup".

Hasil tes dari kedua sekolah dibandingkan, pada teknik dasar service atas SMK Negeri 1 Batu lebih baik dibandingkan dengan SMA Negeri 1 Batu dengan rata-rata nilai 24,9. Pada teknik dasar passing bawah SMA Negeri 1 lebih baik dibandingkan SMK Negeri 1 Batu dengan rata-rata 11,5. Pada teknik dasar passing atas SMA Negeri 1 lebih baik dibandingkan SMK Negeri 1 Batu dengan rata-rata 12,5. Pada teknik dasar smash SMA Negeri 1 lebih baik dibandingkan SMK Negeri 1 Batu dengan rata-rata 24,1. Pada teknik dasar block SMA Negeri 1 lebih baik dibandingkan SMK Negeri 1 Batu dengan rata-rata 17,1.

\section{Daftar Rujukan}

Ahmadi. (2007). Pembelajaran Teknik Dasar Permainan Bolavoli. Jakarta: UNJ.

Anggraini, A. W., Agus T., \& Sulistyorini. (2016). Meningkatkan Keterampilan Passing Bawah Menggunakan Latihan Bervariasi pada Siswa Peserta Ekstrakurikuler Bola Voli SMK Negeri 2 Singosari Kabupaten Malang. Jurnal Pendidikan Jasmani, 26(2), 365-380.

Arikunto, S. (2014). Aplikasi Metodologi Penelitian.Yogyakarta: CV Budi Utama.

Fallo, I. S. \& Hendri. 2016. Upaya meningkatkan Keterampilan Smash Permainan Bola Voli Melalaui Pembelajaran Gaya Komando. Jurnal Pendidikan Olahraga, 5(1).

Fauzi. 2011. Penyusunan Battery Tes Olahraga Bolavoli. Yoyakarta: FIK UNY.

Jahja, Y. (2011). Psikologi Perkembangan. Jakarta: PRENADAMEDIA GROUP.

Kompri. (2015). Manajemen Pendidikan. Yogyakarta: Ar-Ruzz Media.

Listina. (2012). Mengenal Olahraga Bolavoli. Jakarta: PT Balai Pustaka.

Nurrochmah, S. (2016). Tes Dan Pengukuran Dalam Pendidikan Jasmani dan Keolahragaan. Malang: Universitas Negeri Malang.

Peraturan Pemerintah Pendidikan Nasional No.39 Tahun 2008 tentang Pembinaan Kesiswaan. Jakarta: Depdiknas.

PP. PBVSI. (2005). Peraturan Permainan Bolavoli. Jakarta: PP. PBVSI.

Siswanto, H. (2012). Peningkatan Ketrampilan Smash Permainan Bola Voli Melalui Metode Resiprokal. Jurnal Media Ilmu Keolahragaan Indonesia, 2(2), 82-88.

Sugiyono. (2014). Metodologi Penelitian Pendidikan. Bandung: Alfabeta.

Sudijono, A. (2005). Pengantar Evaluasi Pendidikan. Jakarta: PT. Raja Grafindo Persada.

Syaleh, M. (2017). Upaya Meningkatkan Hasil Belajar Servis Atas Bola Voli Melalui Media Pembelajaran Lempar Pukul Bola Kertas PAda Siswa Kelas VII SMP. Jurnal Prestasi, 1(1), 23-30.

Wahyuda, T. A., Winarno, M. E. \& Agus T. (2016). Model Latihan Block Permainan Bolavoli pada Kegiatan Ekstrakurikuler di SMK Negeri 6 Malang. Jurnal Pendidikan Jasmani, 26(1), 188-202. 
Sport Science and Health, 3(5), 2021, 284-293

Winarno. (2015). Teknik Dasar dan Taktik Bermain Bolavoli. Malang: Universitas Negeri Malang. Winarno. (2017). Metodologi Penelitian Dalam pendidikan Jasmani. Malang: Universitas Negeri Malang.

Yuniawan, A. E., Henny S., \& Cahyo Y. (2012). Modifikasi Model Pembelajaran Bola Voli Melalui Permainan Bola Voli Mini Berlapis. Journal of Physical Education, Sport, Health and Recreation, 1(4). 